Supporting Information

for

Brief Article of J. Med. Chem.: jm060025u

\title{
Identification of a New Class of Low Molecular Weight Antagonists against the Chemokine Receptor CXCR4 Having the Dipicolylamine Zinc(II) Complex Structure
}

\author{
Hirokazu Tamamura,,$* *$ Akio Ojida, $\ddagger$ Teppei Ogawa, ${ }^{\dagger}$ Hiroshi Tsutsumi, ${ }^{\#}$ Hiroyuki Masuno, \\ Hideki Nakashima, $\neq$ Naoki Yamamoto,, Itaru Hamachi,, \\ and Nobutaka Fujii†,*
}

Contents: pages S2-3: experimental procedures for novel synthetic compounds, 18 and 19. page S4: Experimental data: inhibition against $\mathrm{Ca}^{2+}$ mobilization. page S5: Experimental data: inhibition of [ $\left.{ }^{125} \mathrm{I}\right]$-CXCL12 binding to CXCR4 transfectants. page S6: Experimental data: inhibition of [ $\left.{ }^{125} \mathrm{I}\right]-\mathrm{MIP}-1 \alpha$ binding to CCR5 transfectants and [125I]-sphingosine 1-phosphate binding to EDG3 transfectants. 


\section{Bis(3,3'-dipicolylamino)-p-xylene Zn complex (18)}

To a stirred solution of $p$-xylenediamine $(50 \mathrm{mg}, 0.367 \mathrm{mmol})$ and pyridine-3-carbaldehyde (0.345 mL, $3.67 \mathrm{mmol})$ in $\mathrm{ClCH}_{2} \mathrm{CH}_{2} \mathrm{Cl}-\mathrm{DMF}(9: 1(\mathrm{v} / \mathrm{v}), 2.75 \mathrm{~mL})$ was added sodium triacetoxyborohydride $\left[\mathrm{NaBH}(\mathrm{OAc})_{3}\right](0.95 \mathrm{~g}, 4.48 \mathrm{mmol})$ at $0{ }^{\circ} \mathrm{C}$, and the mixture was stirred at room temperature for $5 \mathrm{~h}$. The reaction mixture was diluted with $\mathrm{H}_{2} \mathrm{O}(300 \mathrm{~mL})$. The crude compound was purified by preparative HPLC to give the zinc-free compoound 24 as a freeze-dried oil of TFA salts. The residue was treated with $4 \mathrm{M} \mathrm{HCl}$ in dioxane $(5 \mathrm{~mL})$, following by concentration under reduced pressure. Addition of $\mathrm{Et}_{2} \mathrm{O}$ to the residue gave $80.7 \mathrm{mg}(0.112$ mmol, 31\% yield from $p$-xylenediamine) of 24 as colorless crystals of $\mathrm{HCl}$ salts. 24: ${ }^{1} \mathrm{H}-\mathrm{NMR}$ (400 MHz, CD $\left.{ }_{3} \mathrm{OD}\right) \delta 8.90$ (br s, 4H), 8.69 (br d, 4H), 8.68 (br d, 4H), 7.99 (t, J = 7.2 Hz, 4H), 7.34 (br m, 4H) 3.97-3.60 (m, 12H); IS-MS, $\mathrm{m} / \mathrm{z}$ calcd for $\mathrm{C}_{32} \mathrm{H}_{33} \mathrm{~N}_{6}\left(\mathrm{MH}^{+}\right)$: 501.7, found: 502.0. 24 as $\mathrm{HCl}$ salts $(45.8 \mathrm{mg}, 0.0637 \mathrm{mmol})$ was basified with aq. $4 \mathrm{M} \mathrm{NaOH}$ at $0{ }^{\circ} \mathrm{C}$, and the mixture was extracted with EtOAc. The extract was washed with brine and dried over $\mathrm{MgSO}_{4}$. After removal of the solvent under reduced pressure, the resulting $\mathrm{HCl}$-free 24 was solved in MeOH-THF ( $8: 1(\mathrm{v} / \mathrm{v}), 2.0 \mathrm{~mL})$. To the solution of $\mathbf{2 4}$ was added dropwise aqueous solution of $0.5 \mathrm{M} \mathrm{Zn}\left(\mathrm{NO}_{3}\right)_{2}(0.267 \mathrm{~mL}, 0.134 \mathrm{mmol})$ at room temperature, and the mixture was stirred at this temperature overnight. After removal of the organic solvent under reduced pressure and lyophilization, the residue was washed with $\mathrm{H}_{2} \mathrm{O}$ followed by subsequent recrystallization with $\mathrm{MeOH}-\mathrm{EtOH}$ to give $15.7 \mathrm{mg}(0.0249 \mathrm{mmol}, 39 \%$ yield from 24) of $\mathbf{1 8}$ as colorless crystals. IS-MS, $m / z$ calcd for $\mathrm{C}_{32} \mathrm{H}_{33} \mathrm{~N}_{6} \cdot 2 \mathrm{Zn}\left(\mathrm{MH}^{+}\right): 629.1$, found: 629.5 .

\section{Bis(4,4'-dipicolylamino)-p-xylene Zn complex (19)}

According to a procedure identical with that described for the preparation of $\mathbf{2 4}$ and 18, 25 and 19 were synthesized. 25: $21 \%$ yield from $p$-xylenediamine as colorless crystals of $\mathrm{HCl}$ salts. ${ }^{1} \mathrm{H}-\mathrm{NMR}\left(400 \mathrm{MHz}, \mathrm{CD}_{3} \mathrm{OD}\right) \delta 8.92$ (br m, 8H), 8.70 (br m, 8H), 7.84 (br m, 4H) 4.10-3.60 (m, 
$12 \mathrm{H}$ ); IS-MS, $\mathrm{m} / \mathrm{z}$ calcd for $\mathrm{C}_{32} \mathrm{H}_{33} \mathrm{~N}_{6}\left(\mathrm{MH}^{+}\right)$: 501.7, found: 502.0. 19: $80 \%$ yield from 25 as colorless crystals. IS-MS, $m / z$ calcd for $\mathrm{C}_{32} \mathrm{H}_{33} \mathrm{~N}_{6} \cdot 2 \mathrm{Zn}\left(\mathrm{MH}^{+}\right): 629.1$, found: 628.0. 
Experimental data: inhibition against $\mathrm{Ca}^{2+}$ mobilization induced by CXCL12 stimulation through CXCR4 (Compounds 2, 5, 7 and 12). All data are the mean values for at least two experiments.

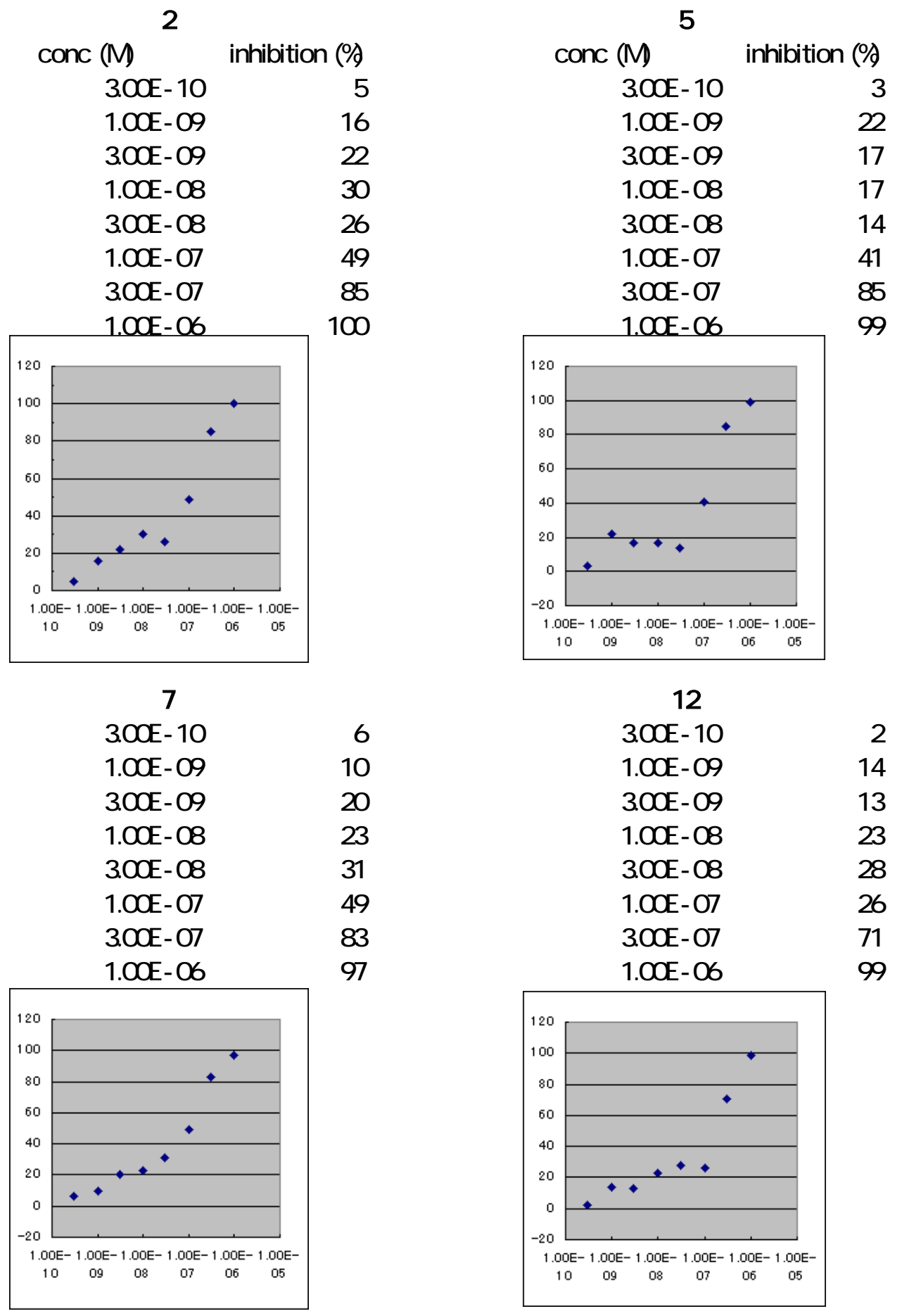


Experimental data: inhibition of [125I]-CXCL12 binding to CXCR4 transfectants of CHO cells (Compounds 2, 5, 7 and 12). All data are the mean values for at least two experiments.

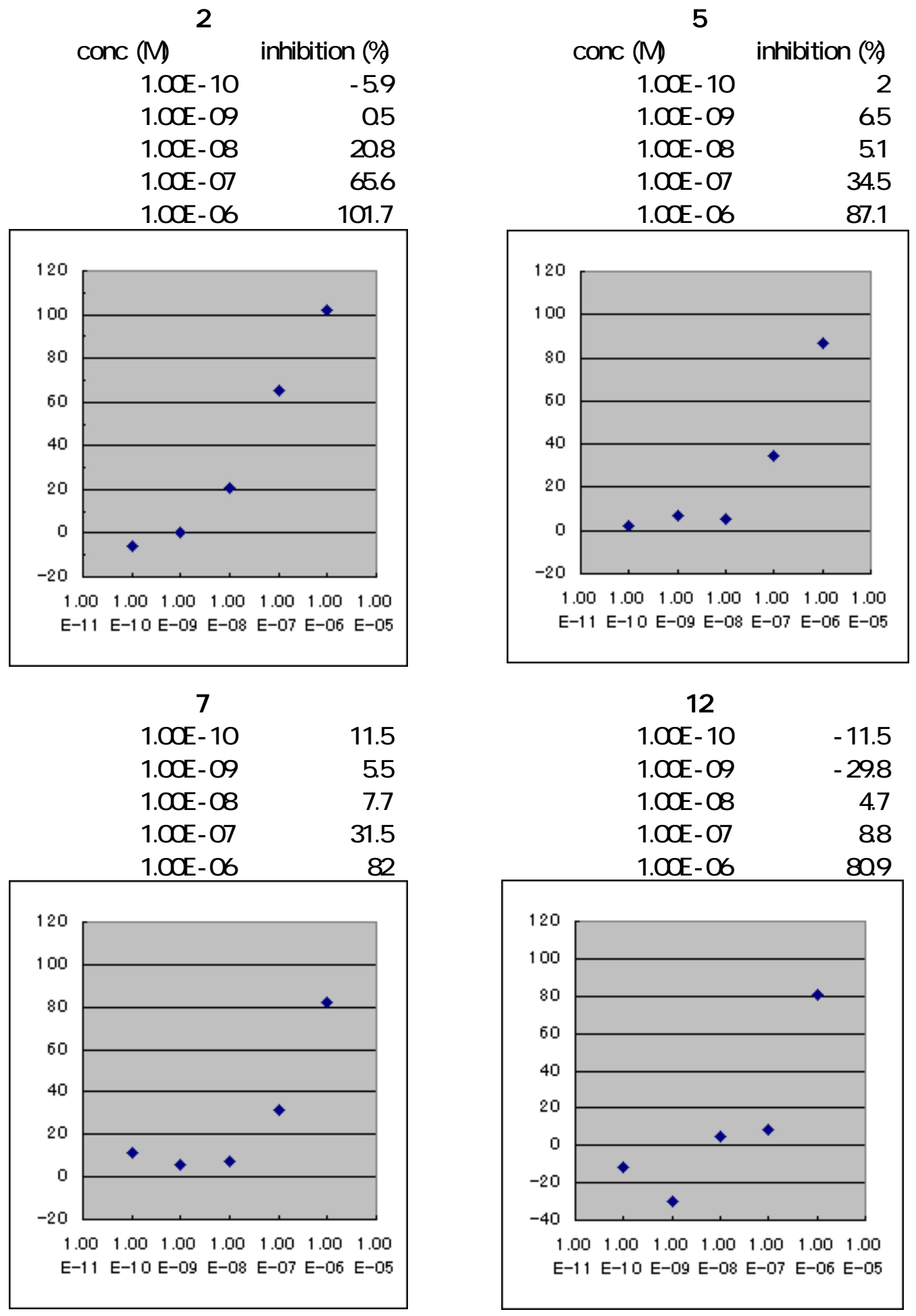


Experimental data: inhibition of [125I]-MIP-1 $\alpha$ binding to CCR5 transfectants of CHO cells and [125I]-sphingosine 1-phosphate binding to EDG3 (GPCR) transfectants of CHO cells (Compounds 2, 5, 7 and 12). All data are the mean values for at least two experiments.

\begin{tabular}{|c|c|c|c|}
\hline \multicolumn{2}{|c|}{2} & \multicolumn{2}{|c|}{5} \\
\hline conc $(\mathrm{M})$ & inhibition & conc $(\mathrm{M})$ & inhibition \\
\hline $1.00 \mathrm{E}-05$ & $<25$ & 1.00E- 05 & $<25$ \\
\hline \multicolumn{2}{|c|}{7} & \multicolumn{2}{|c|}{12} \\
\hline conc $(\mathrm{M})$ & $\begin{array}{c}\text { inhibition } \\
\text { (\%) }\end{array}$ & conc (M) & $\begin{array}{c}\text { inhibition } \\
(\%)\end{array}$ \\
\hline 1.00E- 05 & $<25$ & 1.00E- 05 & $<25$ \\
\hline
\end{tabular}

calcium monilization (sphingosine 1- phosphate (S1P)/EDG3)

\begin{tabular}{|c|c|c|c|}
\hline \multicolumn{2}{|c|}{2} & \multicolumn{2}{|c|}{5} \\
\hline conc $(\mathrm{M})$ & $\begin{array}{c}\text { inhibition } \\
\text { (\%) }\end{array}$ & conc $(\mathrm{M})$ & $\begin{array}{c}\text { inhibition } \\
(\%)\end{array}$ \\
\hline 3.00E- 05 & $<25$ & 3.00E- 05 & $<25$ \\
\hline & 7 & & 2 \\
\hline conc (M) & $\begin{array}{c}\text { inhibition } \\
(\%)\end{array}$ & conc (M) & $\begin{array}{c}\text { inhibition } \\
(\%)\end{array}$ \\
\hline 3.00E- 05 & $<25$ & 3.00E- 05 & $<25$ \\
\hline
\end{tabular}

